\title{
PENGARUH MEDIA SOSIAL DALAM MEMBANGUN OPINI PUBLIK
}

\author{
Oleh: Muhammad Qadri ${ }^{1}$ \\ Bawaslu Provinsi Sulawesi Tengah \\ Email: qadrimuhammad.shorinji@gmail.com
}

\begin{abstract}
This paper discusses how the influence of social media in building public opinion. The use of social media has a positive impact in the process of social, political and economic interactions. The use of social media also makes it easy to access various information needed, makes it easy to communicate rarely far away and social media can also be a tool to make new friends. Of the various positive impacts of social media, it turns out that it also has a negative impact if users cannot properly filter news or information that contains divisions, hoaxes or fake news, sara issues, religion and others that are carried out by people who are not responsible, then it can cause chaos which will certainly split the unity.
\end{abstract}

Keywords: Social Media, Public Opinion, Information Technology

\begin{abstract}
Abstrak
Tulisan ini membahas Bagaimana Pengaruh Media Sosial Dalam Membangun Opini Publik. Penggunaan media sosial memberikan dampak yang positif dalam proses melakukan interaksi sosial, politik maupun ekonomi. penggunaan media sosial juga memberikan kemudahan dalam mengakses berbagai informasi yang dibutuhkan, memberikan kemudahan dalam berkomunaksi jarang jauh serta dengan media sosial juga dapat menjadi alat untuk mendapatkan teman baru. Dari berbagai dampak positif media sosial, ternyata juga memiliki dampak negatif yang apabila jika penggunanya tidak dapat memfilter dengan baik akan beritaberita atau informasi yang mengandung perpecahan, hoax atau berita bohong, isu sara, agama dan lainnya yang dilakukan oleh orang-orang yang tidak bertanggung jawab, maka dapat menimbulkan kericuhan yang bisa dipastikan akan memecah belah persatuan.
\end{abstract}

Katakunci: Media Sosial, Opini Publik, Teknologi Informasi

Pendahuluan

Perkembangan teknologi informasi semakin mempengaruhi hidup manusia. Seiring perkembanga zaman, masyarakat Indonesia mulai mengenal adanya internet, televisi, radio dan teknologi lainnya yang mengarah pada

${ }^{1}$ Muhammad Qadri, merupakan Staff HUMAS pada BAWASLU Provinsi Sulawesi Tengah 
kemudahan masyarakat dalam mengkses berbagai jenis informasi. Salah satunya adalah Internet yang merupakan wujud perpaduan antara arus komunikasi dengan perkembangan teknologi. Salah satu layanan berbasis web yang paling banyak diakses masyrakat adalah situs jejaring sosial. Dengan majunya teknologi yang berbasis media sosial, menjadikan masyarakat dapat dengan mudah berpartisipasi, berbagi informasi, dan menciptakan isi meliputi jejaring sosial seperti instagram, facebook, tweeter, dan media sosial lainnya.

Instagram, facebook, tweeter, dan jejaring sosial lainnya merupakan bentuk media sosial yang paling umum digunakan oleh masyarakat di seluruh dunia. Media sosial memberikan pengaruh yang cukup besar dalam menyampaikan informasi mulai dari informasi terkini seperti dunia pendidikan, sosial, politik, budaya dan lain-lain hingga informasi seputar hal pribadi seperti gaya hidup.

Tren media sosial yang sampai saat ini sudah menjalar di semua kalangan, tak terkecuali anak-anak pun dapat dengan mudah mengakses informasi kemudian dengan mudah pula menyebarkan informasi yang mereka dapatkan, tanpa memahami manfaat maupun mudhoratnya, tanpa memfilter informasi yang mereka dapatkan, dengan kata lain tidak bijak dalam mengelola informasi, sehingga informasi yang disebarkan bisa jadi benar dan bisa jadi sebaliknya atau dengan sebutan trennya BERITA BOHONG/HOAX.

Problematika demikian yang menjadi isu penting dari peran media sosial dalam membangun opini publik, sebab sangat rawan dalam penyalahgunaan media sosial.

Namun media sosial juga merupakan media penyebaran isu yang sangat rawan penyalahgunaanya, tidak sedikit pengguna media sosial yang kurang bijak dan tidak bertanggung jawab dalam memanfaatkan media sosial. Hal ini disebabkan oleh oknum atau pengguna media sosial yang filter dari informasi itu sendiri merupakan sang pengguna media sosial tersebut. Hal ini memberikan pandangan bahwa media Sosial 50\% benar dan 50\% "disetir" tergantung dari pengguna ataupun yang menerima informasi dari media sosialnya. 
Indonesia menjadi negara di Asia yang mengalami pertumbuhan pesat kedua setelah Malaysia dalam mengakses salah satu jejaring sosial (facebook). Meningkatnya pengguna jejaring sosial di Indonesia disebabkan oleh semakin lengkapnya fasilitas akses internet yang dilakukan oleh para produsen telepon seluler dan para penyedia layanan komunikasi. Televisi merupakan media masa elektronik yang paling diminati oleh masyarakat dan paling memberikan pengaruh besar terhadap pengetahuan, motivasi, dan sikap serta perilaku penontonnya. Tanpa memandang usia, jenis kelamin, jabatan, dan sebagainya. Dibandingkan dengan media komunikasi lain, televisi dapat memberi pengaruh yang lebih kuat dibandingkan dengan radio dan surat kabar. Hal ini terjadi karena kekuatan audio visual televisi yang menyentuh segi-segi kejiwaan masyarakat Pengguna media sosial tersebut. Seiring dengan berkembangnya teknologi yang dibuktikan dengan hadirnya smartphone, juga bisa menjadi pengganti dari fungsi televisi, bahkan melalui media smartphone yang memiliki fitur-fitur lengkap dan modern, serta bentuknya yang mini sehingga mudah untuk di bawa kemana saja menjadikan masyarakat dapat dengan mudah mengakses berbagai informasi lebih banyak dibandingkan televisi.

Lalu bagaimana sebenarnya media Sosial dapat mengubah pemikiran publik? Media Sosial bekerja melalui penyebaran informasi. Adanya suatu hal yang dapat menimbulkan perpecahan, maka disitulah media Sosial terlihat secara langsung dapat mempengaruhi pandangan opini publik. Media Sosial bisa saja mengarah kepada kepentingan yang benar atau justru malah sebaliknya. Kecendrungan ini biasanya didasari dari pengaruh yang berkerja pada media Sosial tersebut. Media Sosial kadang ada yang berdiri secara independent. Ada juga yang ditunggangi kepentingan politik oleh beberapa golongan atau kelompok. Bahkan ada juga media Sosial yang bisa ditunggangi pemerintah.

Lebih jauh lagi media Sosial kini berperanan cukup penting dalam memengaruhi masyarakat bagi pembentukan opini publik yang amat diharapkan bagi pelaku politik praktis di negeri ini untuk berhasil memenangkan kontestasi politik. Pada titik ini peranan media Sosial dalam memengaruhi opini publik terhadap tokoh atau pelaku politik praktis boleh jadi bisa berkembang pada iklim 
demokrasi yang tidak sehat dikarenakan pandangan subyektif media Sosial atas tafsiran pemahaman. Mereka yang belum cukup matang dalam memahami sosok pemimpin dan kepemimpinan mungkin bisa saja "terjebak" atau terperangkap oleh skenario besar media Sosial untuk memenangkan kandidat tertentu.

Saking senangnya pelaku media Sosial atas sosok pemimpin tertentu dan keberpihakan yang sangat nampak membuat pemberitaan media Sosial irasional dan tidak lagi mendidik masyarakat dalam mengkritisi hal-hal yang sepatutnya perlu dilakukan. Memang tokoh-tokoh yang diliput dan kerap diberitakan oleh media Sosial akan menjadi popular dan tampak sekali tokoh-tokoh itu juga "menikmati" peliputan tentang dirinya. Bahkan liputan tentang tokoh ini sudah diluar akal sehat karena seringkali diliput hal-hal yang tidak ada hubungannya dengan tugas pekerjaan utama sang tokoh seperti bernyanyi, makan di warteg dan juga ucapan komentar tokoh tersebut atas program yang ditayangkan disejumlah stasiun televisi di Indonesia. Sungguh peliputan ini bukan sesuatu yang baik bagi pendidikan politiik kita malah terkesan dunia politik praktis di negeri ini disejajarkan dengan dunia selebirti-entertaimen yang banyak menayangkan kegiatan-kegiatan berisfat popularitas semata ketimbang bersifat edukasi.

Dari latar belakang diatas maka penulis hendak mengangkat permasalahan dalam penulisan makalah ini yaitu "Bagaimana Pengaruh Media Sosial Dalam Membangun Opini Publik"

\section{Pembahasan}

\section{Penggunaan Media Sosial.}

\section{Pengertian Penggunaan Media Sosial}

Dalam Kamus Besar Bahasa Indonesia, penggunaan memiliki arti proses, cara perbuatan memakai sesuatu, atau pemakaian. ${ }^{2}$ Penggunaan merupakan kegiatan dalam menggunakan atau memakai sesuatu seperti sarana atau barang. Menurut Ardianto dalam bukunya yang berjudul Komunikasi Massa, tingkat

\footnotetext{
${ }^{2}$ Depdiknas RI, Kamus Besar Bahasa Indonesia, (Jakarta : Balai Pustaka, 2002), Hlm. 852
} 
penggunaan media dapat dilihat dari frekuensi dan durasi dari penggunaan media tersebut. $^{3}$

Menurut Lometti, Reeves, dan Bybee penggunaan media oleh individu dapat dilihat dari tiga hal, yaitu:

a. Jumlah waktu, hal ini berkaitan dengan frekuensi, intensitas, dan durasi yang digunakan dalam mengakses situs;

b. Isi media, yaitu memilih media dan cara yang tepat agar pesan yang ingin disampaikan dapat dikomunikasikan dengan baik.

c. Hubungan media dengan individu dalam penelitian ini adalah keterkaitan pengguna dengan media sosial. ${ }^{4}$

Media sosial sendiri didefinisikan sebuah media online, dengan para penggunanya bisa dengan mudah berpartisipasi, berbagi, dan menciptakan isi meliputi blog, jejaring sosial, wiki, forum dan dunia virtual. Blog, jejaring sosial dan wiki merupakan bentuk media sosial yang paling umum digunakan oleh masyarakat di seluruh dunia. Andreas Kaplan dan Michael Haenlein mendefinisikan media sosial sebagai "sebuah kelompok aplikasi berbasis internet yang membangun di atas dasar ideologi dan teknologi Web 2.0, dan yang memungkinkan penciptaan dan pertukaran user-generated content". 5

Media sosial adalah media online yang mendukung interaksi sosial. Sosial media menggunakan teknologi berbasis web yang mengubah komunikasi menjadi dialog interaktif. Beberapa situs media sosial yang populer sekarang ini antara lain : Blog, Twitter, Facebook, Instagram, Path, dan Wikipedia. Definisi lain dari sosial media juga di jelaskan oleh Van Dijk media sosial adalah platform media yang memfokuskan pada eksistensi pengguna yang memfasilitasi mereka dalam

\footnotetext{
3 Ardianto Elvinaro, Komunikasi Massa : Suatu Pengantar, (Bandung : Simbiosa Rekatama Media, 2004), Hlm. 125

${ }^{4}$ Thea Rahmani, 2016, Penggunaan Media Sosial Sebagai Penguasaan Dasar-Dasar Fotografi Ponsel, Universitas Islam Negeri Sunan Kalijaga Yogyakarta, Hlm. 22.

${ }^{5}$ Michael Haenlein, Users of the world, unite! The cHlmlenges and opportunities of Social Media". (Business Horizons, 2010), Hlm. 59-68
} 
beraktivitas maupun berkolaborasi. Karena itu, media sosial dapat dilihat sebagai fasilitator online yang menguatkan hubungan antar pengguna sekaligus sebagai sebuah ikatan sosial. ${ }^{6}$

Menurut Shirky media sosial dan perangkat lunak sosial merupakan alat untuk meningkatkan kemampuan pengguna untuk berbagi (to share), bekerja sama (to co-operate) diantara pengguna dan melakukan tindakan secara kolektif yang semuanya berada diluar kerangka institusional meupun organisasi. Media sosial adalah mengenai menjadi manusia biasa. Manusia biasa yang saling membagi ide, bekerjasama, dan berkolaborasi untuk menciptakan kreasi, berpikir, berdebat, menemukan orang yang bisa menjadi teman baik, menemukan pasangan, dan membangun sebuah komunitas. Intinya, menggunakan media sosial menjadikan kita sebagai diri sendiri. ${ }^{7}$

Beberapa pengertian diatas tentang penggunaan media sosial maka dapat disimpulkan penggunaan media sosial adalah proses atau kegiatan yang dilakukan seseorang dengan sebuah media yang dapat digunakan untuk berbagi informasi, berbagi ide, berkreasi, berfikir, berdebat, menemukan teman baru dengan sebuah aplikasi online yang dapat digunakan melalui smartphone (telefon genggam).

\section{Fungsi Media Sosial}

Media sosial memiliki beberapa fungsi sebagai berikut :

a. Media sosial adalah media yang didesain untuk memperluas interaksi sosial manusia menggunakan internet dan teknologi web. Media sosial berhasil mentransformasi praktik komunikasi searah media siaran dari satu institusi media ke banyak audience ("one to many") menjadi praktik komunikasi dialogis antar banyak audience ("many to many").

b. Media sosial mendukung demokratisasi pengetahuan dan informasi.

\footnotetext{
${ }^{6}$ Rulli Nasrullah, Media Sosial : Perspektif Komunikasi, Budaya, dan Sosioteknologi, (Bandung : Remaja Rosdakarya, 2017), Hlm. 11

${ }^{7}$ Ibid 11 .
} 
c. Mentransformasi manusia dari pengguna isi pesan menjadi pembuat pesan itu sendiri.

\section{Manfaat Media Sosial}

Media sosial merupakan bagian dari sistem relasi, koneksi dan komunikasi. Berikut ini sikap yang harus kita kembangkan terkait dengan peran, dan manfaat media sosial :

\section{a. Sarana belajar, mendengarkan, dan menyampaikan.}

Berbagai aplikasi media sosial dapat dimanfaatkan untuk belajar melalui beragam informasi, data dan isu yang termuat di dalamnya. Pada aspek lain, media sosial juga menjadi sarana untuk menyampaikan berbagai informasi kepada pihak lain. Konten-konten di dalam media sosial berasal dari berbagai belahan dunia dengan beragam latar belakang budaya, sosial, ekonomi, keyakinan, tradisi dan tendensi. Oleh karena itu, benar jika dalam arti positif, media sosial adalah sebuah ensiklopedi global yang tumbuh dengan cepat. Dalam konteks ini, pengguna media sosial perlu sekali membekali diri dengan kekritisan, pisau analisa yang tajam, perenungan yang mendalam, kebijaksanaan dalam penggunaan dan emosi yang terkontrol.

\section{b. Sarana dokumentasi, administrasi dan integrasi.}

Bermacam aplikasi media sosial pada dasarnya merupakan gudang dan dokumentasi beragam konten, dari yang berupa profil, informasi, reportase kejadian, rekaman peristiwa, sampai pada hasil-hasil riset kajian. Dalam konteks ini, organisasi, lembaga dan perorangan dapat memanfaatkannya dengan cara membentuk kebijakan penggunaan media sosial dan pelatihannya bagi segenap karyawan, dalam rangka memaksimalkan fungsi media sosial sesuai dengan target-target yang telah dicanangkan. Beberapa hal yang bisa dilakukan dengan media sosial, antara lain membuat blog organisasi, mengintegrasikan berbagai lini di perusahaan, menyebarkan konten yang relevan sesuai target di masyarakat, atau memanfaatkan media sosial sesuai kepentingan, visi, misi, tujuan, efisiensi, dan efektifitas operasional organisasi.

c. Sarana perencanaan, strategi dan manajemen. 
Akan diarahkan dan dibawa ke mana media sosial, merupakan domain dari penggunanya. Oleh sebab itu, media sosial di tangan para pakar manajemen dan marketing dapat menjadi senjata yang dahsyat untuk melancarkan perencanaan dan strateginya. Misalnya saja untuk melakukan promosi, menggaet pelanggan setia, menghimpun loyalitas customer, menjajaki market, mendidik publik, sampai menghimpun respons masyarakat.

\section{d. Sarana kontrol, evaluasi dan pengukuran.}

Media sosial berfaedah untuk melakukan kontrol organisasi dan juga mengevaluasi berbagai perencanaan dan strategi yang telah dilakukan. Ingat, respons publik dan pasar menjadi alat ukur, kalibrasi dan parameter untuk evaluasi. Sejauh mana masyarakat memahami suatu isu atau persoalan, bagaimana prosedur-prosedur ditaati atau dilanggar publik, dan seperti apa keinginan dari masyarakat, akan bisa dilihat langsung melalui media sosial. Pergerakan keinginan, ekspektasi, tendensi, opsi dan posisi pemahaman publik akan dapat terekam dengan baik di dalam media sosial. Oleh sebab itu, media sosial juga dapat digunakan sebagai sarana preventif yang ampuh dalam memblok atau memengaruhi pemahaman public

\section{Opini Publik}

\section{Pengertian Opini Publik.}

Istilah opini publik dapat dipergunakan untuk menandakan setiap pengumpulan pendapat yang dikemukakan individu-individu. Menurut Santoso Sastropoetro istilah opini publik sering digunakan untuk menunjuk kepada pendapat-pendapat kolektif dari sejumlah besar orang. ${ }^{8}$ secara etimologi opini publik adalah terjemahan dari bahasa Inggris yaitu public opinion. Sementara public opinion berasal dari bahasa latin yaitu opinari dan publicus. Opinari mempunyai arti fikir atau menduga sedangkan publicus artinya adalah milik masyarakat luas. Secara sederhana opini bisa diartikan pendapat. Tapi setidaknya ada sebuah ekspresi dari pendapat tersebut baik secara verbal maupun

\footnotetext{
${ }^{8}$ Santoso Sastropoetro, Pendapat Publik, Pendapat Umum, dan Pendapat KHImayak dalam Komunikasi Sosial, (Bandung: Remaja Rosdakarya, 1990), hlm. 49
} 
non verbal. Selama pendapat itu belum di ekspresikan maka saat itu pendapat itu adalah pendapat pribadi. Menurut Leonard W. Dood, suatu isu baru dikatakan sebagai opini publik setelah masyarakat mengungkapkannya ${ }^{9}$

Berbeda dengan kerumunan, publik lebih merupakan kelompok yang tidak merupakan kesatuan. Interaksi terjadi secara tidak langsung melalui alat-alat komunikasi, seperti pembicaraan-pembicaraan pribadi berantai, melalui desasdesus, melalui surat kabar, radio, televisi dan film. Alat-alat penghubung ini memungkinkan "publik" mempunyai pengikut yang lebih luas dan lebih besar jumlahnya. Publik dapat didefinisikan sebagai sejumlah orang yang mempunyai minat, kepentingan, atau kegemaran yang sama.

Publik dimengerti sebagai bentuk koordinasi kolektif yang memiliki tiga hal, yaitu: pertama, identitas lebih kurang sama. Kedua, setuju atas diagnostik masalah (sebab, tanggung jawab, dan pemecahan). Ketiga, ikut terlibat untuk suatu upaya kolektif. Jadi, opini selalu kontekstual terkait dengan budaya dan dinamika perdebatan ${ }^{10}$. Dalam hal ini, mengapa opini publik perlu diungkapkan. Karena selama tidak diungkapkan tidak akan terjalin sebuah komunikasi dan selamanya pendapat itu ada dalam diri. Sebenarnya antara sikap dan pernyataan mempunyai arti yang berbeda. Sikap ada dalam diri seseorang, sedangkan pernyataan merupakan keluar dari diri seseorang. Tapi ada kesinambungan antara sikap dan pernyataan dalam menghadapi suatu persoalan atau situasi tertentu Menurut Leonard W. Dood pendapat umum adalah sikap orang-orang mengenai sesuatu soal, dimana mereka merupakan anggota dari sebuah masyarakat yang sama. ${ }^{11}$

Menurut Dra. Djoenaesih S. Sunarjo, ciri-ciri opini itu adalah9:

a. Selalu diketahui dari pernyataan pernyataannya;

b. Merupakan sintesa atau kesatuan dari banyak pendapat;

c. Mempunyai pendukung dalam jumlah besar

\footnotetext{
${ }^{9}$ Hafied Cangara, Komunikasi politik, Konsep, Teori, dan Strategi, (Jakarata: Raja Grafindo Persada,2009),hlm.158

${ }^{10}$ Haryatmoko, "Mengarahkan Opini Publik", kliping harian Kompas, 2 Februari 2009

${ }^{11}$ Nikmah Hadiati S, Opini Publik, (Pasuruan: Lunar Jaya,2012), hlm.5
} 


\section{Perkembangan Opini Publik}

Sebagaimana yang sudah dijelaskan diatas bahwa opini publik merupakan serapan dari bahasa Inggris public opinion. Pada awalnya opini publik banyak dikenal dan dipakai pada akhir abad ke-18 di Eropa dan Amerika Serikat. pemakaian istilah itu terutama berkaitan dengan kehidupan sosial pada masa itu. Istilah opini publik. Dalam arti modern pertama kali digunakan oleh Machiavelli.

Menurut Machiavelli bahwa orang yang bijaksana tidak akan mengabaikan opini publik mengenai soal-soal tertentu, seperti pendistribusian jabatan dan kenaikan jabatan. Sementara Rosseau pernah mengatakan bahwa opini publik sebagai "ratu dunia", karena opini public tidak dapat ditaklukkan oleh raja-raja di zaman otoritarian pada abad ke-17 dan ke-18, kecuali ketika opini publik mau dibeli dan menjadi budak para raja. Dan ia juga mengatakan bahwa hukum harus bersumber dari kehendak umum. Kemajuan ilmu, teknologi dan ekonomi pasar pada akhir abad ke-18 dan permulaan abad ke-19 mendorong timbulnya kesadaran yang luas bahwa suara rakyat harus lebih diperhatikan dalam pengambilan keputusan khususnya dalam bidang politik. Hal ini didorong oleh lahirnya tuntutan tentang publik yang ingin juga ikut menentukan nasibnya dalam kehidupan sosial, ekonomi dan politik, terutama dalam perumusan kebijakan publik atau keputusan yang menyangkut kepentingan publik.

Opini publik kemudian juga digunakan dalam kegiatan publik relations yang berkembang di Eropa dan Amerika Serikat setelah perang dunia kedua. Publik relations dipergunakan untuk mempengaruhi publik dan untuk membentuk serta membina opini publik.

Pada abad ke-20 timbul kesadaran tentang pentingya melayani kepentingan umum. Dari sini kemudian opini publik menemukan urgensinya baik dalam politik, sosial, dan ekonomi. Jadilah opini publik sebagai kekuatan diantara institusi pemerintahan dan hukum di Negara terbuka, khususnya di Indonesia. 


\section{Media Sosial Membangun Opini Publik.}

Tak dapat dipungkiri, perkembangan media sosial akhir-akhir ini telah turut andil dalam menentukan kebijakan di negeri kita. Banyak kebijakan yang "terpengaruh" dengan iklim dan tren di media sosial. Pengaruh media sosial yang begitu masif ini tentu menarik untuk dikaji lebih dalam mengingat begitu besarnya kekuatan yang dimiliki dan banyaknya kelompok kepentingan yang memainkan peran signifikan dalam wadah media sosial di dunia maya.

Dalam komunikasi massa terdapat media sosial yang dapat dijadikan sebagai penghubung antara komunikator politik dengan khalayak. Sebagai saluran komunikasi politik, media sosial memiliki kekuatan memberikan pengaruh dan menentukan perilaku politik, karena media sosial dapat berperan dalam membentuk opini publik. Pengelolaan opini publik yang baik, memiliki peran dalam memenangi satu pertarungan untuk memperoleh pengaruh dari kalangan masyarakat. Bagi kekuatan politik yang akan ikut bertarung dalam pemilihan umum, seperti dalam pemilihan presiden, kepala daerah dan anggota legislatif, penting untuk memanfaatkan media sosial secara efisien dan efektif untuk menyampaikan pesan-pesan politiknya. Melalui media sosial, substansi pesanpesan politik lebih cepat dan mudah dicerna oleh khalayak, sebab setiap saat khalayak dapat mengakses informasi tanpa halangan dan batas geografis. Media sosial juga sangat efektif digunakan sebagai media komunikasi khususnya dalam memberikan informasi dan menerima umpan balik dari khalayak. Umpan balik dari khalayak dapat mendekatkan dan merapatkan hubungan antara komunikator politik dengan masyarakat. Terlebih lagi dewasa ini, penggunaan media sosial di kalangan masyarakat semakin populer dan berkembang, hingga ke pelosok pedesaaan. Sehingga dengan kemasan informasi yang baik, khalayak akan mudah memahami pesan-pesan politik yang disampaikan oleh komunikator politik. Pada akhirnya, melalui penyampaian pesan-pesan politik yang tepat dan dilakukan secara efektif akan mampu menarik simpati masyarakat sehingga mereka akan menerima maksud yang diinginkan oleh komunikator politik.

Begitu kuatnya pengaruh medsos dalam mengatur ritme opini publik membuat daya tarik medsos bagi kelompok kepentingan semakin kuat. Akhirnya, 
apabila setiap ada perhelatan pemilu atau pilkada, ada formasi tertentu yang khusus menjadi "pasukan cyber". Tugasnya adalah selain menangkis serangan dari pihak lawan dan berkampanye, juga menembak lawan. Sehingga tidak heran jika sampai terjadi beberapa kasus "twitwar" (perang kata-kata di Twitter) atau "facebook war" (perang kata-kata di Facebook) yang bukan hanya terjadi di dunia maya, namun sudah merambah pada dunia nyata.

Dari keadaan yang ada dan pentingnya media sosial dalam dasawarsa ini, tak salah juga kiranya media social menjadi entitas "partai maya". Sebutan dengan menggunakan istilah "partai maya" hanyalah ungkapan bahwa telah terjadi miskanalisasi artikulasi dan agregasi kepentingan yang ada dalam masyarakat, khususnya menyangkut fungsi yang dimiliki oleh partai politik dan juga pemerintah. Pada akhirnya kondisi ini memaksa publik mencari jalan untuk dapat menyalurkan aspirasinya. Tersumbatnya kanal aspirasi ini akhirnya menyebabkan pilihan jatuh pada media sosial.

Adanya kebuntuan aspirasi ini menyebabkan semakin intensnya pengguna media sosial. Melihat kenyataan ini, para penyelenggara negara pun akhirnya banyak yang menjadikan media sosial sebagai jembatan untuk menyerap aspirasi publik di samping juga menjadi media sosialisasi program atau kebijakan yang telah dilakukannya. Sebut saja Gubernur Jawa Tengah Ganjar Pranowo, Gubernur Jawa Barat Ridwan Kamil, Gubernur Kepulauan Bangka Belitung Erzaldi Rosman Djohan, dan juga Presiden Joko Widodo aktif dalam media sosial.

Fenomena media sosial yang semakin masif ditambah juga dengan kemudahan akses baik melalui komputer maupun gadget (smartphone) serta media portabel lainnya menambah semarak permedsosan di Tanah Air. Selain sebagai penyuara aspirasi, media sosial juga berfungsi sebagai kontrol sosial. Artinya jika ada kebijakan yang dirasakan merugikan kepentingan publik dan cenderung tidak populer, maka publik akan meresponsnya dengan cepat. Opini publik yang tergalang melalui media sosial juga menjadi amunisi untuk dapat menekan para pembuat kebijakan terkait dengan isu publik tersebut. 
Dalam beberapa kasus, medsos bahkan telah menggeser peran media konvensional. Bukan hanya berita positif yang disiarkan medsos. Berita bohong (hoaks), berita palsu (fake news), atau informasi negatif lainnya juga disiarkannya. Informasi dari media sosial itu, termasuk yang negatif, bahkan mampu menggilas opini publik yang telah terbentuk oleh media konvensional.

Media sosial, sarana atau kanal pergaulan sosial lewat jalur online di internet itu, kini banyak digunakan masyarakat untuk memperoleh dan menyebarkan informasi. Media konvensional adalah media massa seperti media cetak (koran, majalah), media elektronik (radio dan televisi), dan online (internet). Sebelum ada medsos, media konvensional menjadi andalan dalam pembentukan opini publik.

Medsos mempunyai karakter yang tak dimiliki media konvensional. Selain bisa disebarkan ke banyak pihak, pesan media sosial tidak terkontrol. Penerima menentukan sendiri kapan membuka informasi dan berinteraksi. Sementara itu, media konvensional, kendati memiliki kebebasan pers, harus memperhatikan berbagai keterbatasan seperti penyaringan berita (gate keeper), kode etik dan regulasi, serta tanggung jawab sosial yang di Indonesia dirumuskan sebagai bebas bertanggung jawab. Karena keterbatasan itulah medsos, dalam pembentukan opini publik, mulai menggeser peran media massa konvensional. Medsos tidak memiliki pembatasan, tanpa kontrol, bisa lebih cepat, mudah diakses dan bisa berinteraksi langsung dengan khalayak.

Menurut data media komunikasi dari Direktorat Jenderal Informasi dan Komunikasi Publik (IPK), Kementerian Komunikasi dan Informatika tahun ini, jumlah media daring 2.011. Sementara itu, media konvensional, koran, dan majalah 567 penerbit, televisi 194 stasiun, dan radio 1.165 stasiun.

Yang menarik, jumlah telepon seluler (ponsel) yang beredar 374 juta atau lebih besar (142\%) daripada 262 juta penduduk Indonesia. Data pengguna internet 132,7 juta (51,3\%), pengguna medsos yang aktif mencapai 106 juta atau 
40\%. Dalam pembentukan opini publik di Indonesia, angka 106 juta pengguna medsos itu pasti memiliki peran yang menentukan ${ }^{12}$.

Berdasarkan karakter dan jumlah penggunanya yang terus meningkat, medsos diharapkan 'hanya' menyajikan informasi positif agar opini publik yang terbentuk pun bermanfaat bagi masyarakat. Produsen dan pengguna medsos mesti mengacu pada etika atau moralitas berkomunikasi, serta regulasi yang berlaku. Dalam UU Informasi dan Transaksi Elektronik (UU ITE) Nomor 19/2016 dirumuskan aturan main bermedsos. Mereka dilarang mendistribusikan, menstransmisikan, dan membuat dapat diakses informasi elektronik atau dokumen elektronik yang memiliki muatan melanggar kesusilaan, perjudian, penghinaan atau pencemaran nama baik, serta pemerasan atau pengancaman.

\section{KESIMPULAN.}

Adapun pengaruh dari media sosial dalam membangun opini publik adalah, dimana komunikasi publik terdapat media sosial yang dapat dijadikan sebagai penghubung antara komunikator publik atau bahkan politik dengan masyarakat. Sebagai saluran komunikasi publik, media sosial memiliki kekuatan memberikan pengaruh dan menentukan perilaku politik, karena media sosial dapat berperan dalam membentuk opini publik. Pengelolaan opini publik yang baik, memiliki peran dalam memenangi satu pertarungan untuk memperoleh pengaruh dari kalangan masyarakat.

Media sosial juga sangat efektif digunakan sebagai media komunikasi khususnya dalam memberikan informasi dan menerima umpan balik dari khalayak. Umpan balik dari khalayak dapat mendekatkan dan merapatkan hubungan antara komunikator publik atau bahkan politik dengan masyarakat. Terlebih lagi dewasa ini, penggunaan media sosial di kalangan masyarakat semakin populer dan berkembang, hingga ke pelosok pedesaaan. Sehingga dengan kemasan informasi yang baik, khalayak akan mudah memahami pesanpesan politik yang disampaikan oleh komunikator publik. Pada akhirnya, melalui penyampaian pesan-pesan politik yang tepat dan dilakukan secara

12 https://mediaindonesia.com/read/detail/124901-opini-publik-dari-media-sosial 
efektif akan mampu menarik simpati masyarakat sehingga mereka akan menerima maksud yang diinginkan oleh komunikator publik.

\section{DAFTAR PUSTAKA}

Ardianto Elvinaro, Komunikasi Massa : Suatu Pengantar, (Bandung : Simbiosa Rekatama Media, 2004.

Depdiknas RI, Kamus Besar Bahasa Indonesia, (Jakarta : Balai Pustaka, 2002)

Thea Rahmani, 2016.

Hafied Cangara, Komunikasi politik, Konsep, Teori, dan Strategi, (Jakarata: Raja Grafindo Persada,2009.

Haryatmoko, "Mengarahkan Opini Publik", kliping harian Kompas, 2 Februari 2009.

Michael Haenlein, Users of the world, unite! The challenges and opportunities of Social Media". (Business Horizons, 2010.

Nikmah Hadiati S, Opini Publik, (Pasuruan: Lunar Jaya,2012.

Penggunaan Media Sosial Sebagai Penguasaan Dasar-Dasar Fotografi Ponsel, Universitas Islam Negeri Sunan Kalijaga Yogyakarta.

Rulli Nasrullah, Media Sosial : Perspektif Komunikasi, Budaya, dan Sosioteknologi, (Bandung : Remaja Rosdakarya, 2017.

Santoso Sastropoetro, Pendapat Publik, Pendapat Umum, dan Pendapat Khalayak dalam Komunikasi Sosial, (Bandung: Remaja Rosdakarya, 1990.

\section{INTERNET:}

https://mediaindonesia.com/read/detail/124901-opini-publik-dari-media-sosial 